\title{
An Analysis of Facilities Available For Instruction to Students of Distance Education Learning Programme in Nigerian Universities
}

\author{
Victor Oziengbe Uwaifo \\ Department of Vocational and Technical Education, Ambrose Alli University, Ekpoma, Edo \\ State, Nigeria \\ E-mail: vuwaifo2009@gmail.com
}

Thomas. Nnaji Odah

Department Of Vocational And Technical Education, Ebonyi State University, Abakaliki,

Ebonyi State, Nigeria

Accepted: January 16, 2012 Published: February 13, 2012

Doi:10.5296/ijld.v2i1.1383ＵRL: http://dx.doi.org/10.5296/ijld.v2i1.1383

\begin{abstract}
The study analysed the available facilities for instruction in the distance learning programme in two Universities in Nigeria's. A sample of 180 students was drawn from the two universities while a questionnaire on Distance Learning Programme Support Facilities (DLPSFQ) was elicited. A systematic analysis of the data showed that facilities were not adequately provided for instruction to the students on the distance learning progranne in these Universities when compaired with what obtains with the regular students of the same University. However, sampled individuals perceived that distance learning was not better organized and implemented than mere lecture centers or school certificate examination training centres as most of the instruction were done in outlet campuses where which lacked adequate training facilities. The problems identified constitute a threat to the academic integrity of graduates from this programme. It was recommended amongst others, that Universities running distance learning education programmes should provide sufficient fund to take care of student's instructional needs as obtainable in the regular education programmes.
\end{abstract}

Key words: Facilities, Support, Distance Learning Programme. 


\section{Introduction}

A high demand for placement into Nigerian universities has occurred in recent years. Okebukola (2007) notes that the Joint Admissions and Matriculation Board (JAMB) a body responsible for placement of young secondary school leavers into the universities could only offer placement opportunities to just $14 \%$ of annual applicants, leaving $86 \%$ of applicants to 'wait for another turn' that may never come. For this singular reason, most applicants who had tried their "luck" several times seek some other opportunities available to them through distance education learning programmes offered as a parallel programme by many universities in Nigeria. This, to some distance learners, is borne out of frustration while some others see it as a second chance having dropped out of the conventional system sometime (Daniel, 2004).

Distance learning is being operationally defined by scholars across the world in many ways. "Any formal instructional approach in which the majority of the instruction occurs at a distance" (Merill, 2003). Learners embarking on distance education programme are faced with many constraints such as: (a) financial constraints, (b) constraints of time, (c) distance (d) physical disabilities, and (e) family commitments (Kinnaman, 1995). Since distance learners are varied according to their socioeconomic backgrounds, adequate provision should be made by institutions in providing administrative and organizational supports otherwise known as learner support (Idrus and Lateh, 2000). As learners differ from place to place, so are their needs (Schamber, 1988). Sampson (2003) purports that distance learners' needs are relative to each learner and his or her institution of learning, yet the need for supports is unique and necessary so as to reduce the rate of drop-out, frustration and fears of failure. It would suffice to say that distance education is best suited to a "mature" learner who has the capacity to access his circumstances, make life choices, who is self-directed and who is an active discoverer and constructor of his own learning (Savery and Duffy, 1995). It is best suited for those who can combine the world of work with their studies (Keegan, 1990). And as much as it is expected of learners who embark on distance education to have had some means of livelihood, yet, this assertion, according to Moore and Kearsley (1996) might not be absolutely true as distance education is not meant for a particular age-group but for anyone who, according to Galusha (2006) are on jobs to keep their homes; physically handicapped/impaired or not privileged to undergo conventional or traditional system of education because of other reasons that are personal.

\section{Facilities for Distance Learning Programme}

According to Moore and Kearsley (1996), there are a number of things that distance learners expect from a distance education course or programme. These include:

1) Information that is up-to-date and authoritative.

2) Courses that are flexible and accommodate different learning styles.

3) Opportunities to do something with what they learn for example assignments and projects).

4) Feedback on their work and progress.

5) Help dealing with administrative or personal problems related to the programme. 
Meeting these expectations should dictate not only how the course or programme is designed and implemented, but also the nature of the teaching/tutoring involved and the student support services provided. At the programme delivery level, administrators or instructors will be responsible for these tasks along with their other instructional duties (Moore and Kearsley, 1996).

Chem (1999) sees educational guidance and counseling as the uttermost amongst the list of preference. Students may need guidance and counseling at a number of different stages in their work as distant learners. At an early stage, they are likely to need advice about whether a particular course promises to suit their particular academic needs at a particular time; advice about how to study for a particular course given; the media used and the format; orientation on what the course embarked upon will eventually earn them; the effects their study will have on their families, on their jobs (for those on jobs), or health and its financial implications on their families and social lives. Oh (2006) emphasizes student support from guidance and counseling as ultimate as it stabilizes their learning effectiveness. He believes that distance learners must be properly guided as the success of individual distance learners begin with registration of courses, choice of study programmes and the burden they put on themselves, about the assessment of their time and resources, the study load, appropriateness of the courses they offer especially with regard to their previous study history and available support facilities. Carr and Ledwith (1980) observe that women, because of their lack of time management skills, form the greater percentage of dropouts among distance learners. Therefore, distance learners' need of organizational and administrative support, according to Kinnaman (1995) is imperative. Funds that must be provided to create an administrative unit to be responsible for students' welfare should not be underestimated. Kinnaman (1995) warns by saying that "without this support, distance education stands the risk of becoming a peripheral activity, without commitment from or significance to the institution and the learners". Distance learning institutions must develop learning course materials of low costs that are affordable to economically less-privileged learners. Miller (2003), Galusha (2006) and Mulrean (2006) agreed with Phi Kappa Phi's the college honour societies standards and guidelines (2005) that providing student support services such as scholarship awards and bursary facilities especially to poor student should gain prominence on the scale of preferences of any institution and government running such a programme, as some students, particularly those without home computers with modems could have difficulty in communicating with the university or teacher. This lack of adequate hardware and subsequent cost barrier of obtaining equipment could place undue hardship on some remote students (Picciano, 2006; Carnevale, 2004). Learners' need of other communication systems such as phones or mails must be met in order to overcome the needs identified above. Only learners who are able to afford possessing a phone or mitigating the in-efficiencies of our post-telecommunication systems will perform well in their course of running the programme (Wang, 2006). Ademokoya (2007) considers the importance of reaching different categories of special needs persons. He also considers accessing these individuals with education through special distance education. This form of education combines relevant principles and practices of special education and distance learning to provide a comprehensive and result oriented education for special learners. However, the present Nigerian special education programmes appear ill-prepared or deficient to offer 
Nigerians with chronic health and physical disorder appropriately relevant educational services. Apart from this, even in advanced countries where special education services have assumed high profile status, the fact remains that a combination of principles and procedures of distance learning and special education are required to provide a multi-disciplinary, broad based and a more result oriented educational services for this individual. Reiterating the above, Idrus and Lateh (2000) state that interactivity is the major support need of distance learners. This, according to them, may take many forms that are not limited to audio or to teacher-student interactions but to the connectivity the students feel with the distance teacher, the local teachers, aides, and facilitators, their peers and their instructional modes. Without connectivity, according to Garrison (1990), distance learning degenerates into old correspondence course model of independent study as the student becomes autonomous and isolated. The purposes of interaction with their instructor/facilitators and fellow students during a course may be to get adequate feedback on their ideas and learning progress, or simply for the pleasures of social contact. This could be achieved by telephone, mail, fax or computer messaging especially in advanced countries where communications through the above-listed means are made available, functional and cheap. Distance learners must interact with their instructors/tutors (teachers) and with themselves on a regular basis. A student directory listing contact information should be provided and learning activities that provide and promote opportunities for students to work together and interact should be made readily available. Are all these support services available and accessible to Nigerian distance learners?

\section{Statement of the Problem}

Distant learners across the world are faced with various student support services or facilities needs which, if not taken care of, can impede the learning progress. In Nigeria, these services and facilities and the level at which they are available must be identified so that distance learning centre/institution stakeholders may be availed of the opportunity of identifying areas for concern and improvement. This study aims to contribute to such an assessment by looking at Eastern Nigeria universities offering distant learning programme.

\section{Research Questions}

The following research questions will guide this study,

1 . Are facilities available in selected distance learning centres?

2 Are distance learners provided with support facilities? Are these support facilities adequate?

3 How do distance learners cope with non-availability of some student support facilities?

\section{Methodology and Data}

The University of Nigeria Nsukka Distance Learning Centre (DLC) had been in existence since 1989. The University of Nigeria Nsukka happens to be one of Nigeria's first university, established in 1964. Nnamdi Azikiwe University Awka started her own distance learning programme in the late 1990s. Distance learners registered at the University of Nigeria Nsukka and Nnamdi Azikiwe University Awka. were used here as a case study. 
The University of Nigeria Nsukka and Nnamdi Azikiwe University Awka distance learning programme is domiciled within the universities, has her distance learners almost everywhere in eastern Nigeria and holds study centres at any available space across the country.

Only lecturers of the University of Nigeria Nsukka and the course materials (modules) produced by the University of Nigeria Nsukka seasoned lecturers are available for the University of Nigeria DLC students, whereas Nnamdi Azikiwe University Awka distance learners are exposed to receiving lectures and course materials from other universities.

Ninety samples from each of the two universities were stratified for the study- University of Nigeria Nsukka DLC and the Nnamdi Azikiwe University Awka DLC, Enugu Centre. The samples were randomly taken to touch each of the faculties and departments taking part in the programme- Education, Arts, the Social Science, Science and Agricultural Science of the two universities. The individuals consisted of both male and female students (Male $=50$ and Female $=40$ ) from each of the two universities' DLC.

A research questionnaire- Distance Learning Programme Support Facilities Questionnaire (DLPSFQ) was constructed and validated by a measurement and evaluation expert using Cronbach alpha coefficient. The reliability of the instrument produced 0.83 . This shows that there was an internal consistency. The instrument which was personally administered by the researcher is a two item questionnaire in three sections: section A focused on the respondent's bio-data. Sections B and C were dichotomous items with section B having available (yes) = 1 , not available $=2$; and section $\mathrm{C}$ having available and adequate $=1$, available but not adequate $=$ 2.

\section{Results}

Table 1. Availability of support facilities at distant learning centres.

\begin{tabular}{lllllc}
\hline S/N & Facilities & Available & \multicolumn{3}{c}{ Not available } \\
\cline { 3 - 6 } & & Frequency & \% & Frequency & \% \\
\hline 1 & Bursary facility & 09 & 5.0 & 171 & 95.0 \\
2 & Scholarship award & 08 & 4.8 & 172 & 95.2 \\
3 & Subsidized tuition & 12 & 6.6 & 168 & 93.4 \\
4 & Hostel accommodation & 50 & 27.7 & 140 & 72.3 \\
5 & Computer system & 27 & 15 & 160 & 75 \\
6 & CD-Rom & 35 & 19.4 & 145 & 70.6 \\
7 & Instructional modules & 69 & 38.3 & 111 & 61.7 \\
8 & Internet use & 15 & 8.3 & 165 & 91.7 \\
9 & Social infrastructure for games & 25 & 26.0 & 155 & 74.0 \\
& and sport & & & & 48.9 \\
10 & Guidance and counselling & 92 & 51.1 & 88 & \\
& services & & & & \\
& Number of observations & $\mathbf{1 8 0}$ & $\mathbf{1 0 0}$ & & \\
\hline
\end{tabular}

As shown in Table 1, 27.7\% out of the 180 sampled individuals indicated that the distance learning centres had hostel accommodation facility available. Majority of the former were registered at the University of Nigeria Nsukka DLC who hold their interactive sessions when 
conventional students would have gone on end of semester or session vacation. $75.0 \%$ said that the centres had no adequate provision to make computer systems available to distance learners. $70.6 \%$ said that CD-Rom could not be provided for distance learners. $38.3 \%$ agreed that the centres could provide learners with instructional materials. However, respondents indicated that all the facilities listed were available in their centres but in varying degrees. Their response also indicated that hostel accommodation, computer systems, CD-Rom, instructional modules and guidance and counseling services were more available than the other facilities.

The Cronbach Alpha Coefficient is a measure of internal consistency of reliability and validity of the instrument used for the study.

Table 2. Provision of support facilities.

\begin{tabular}{llllll}
\hline s/n & Facilities & $\begin{array}{l}\text { Provided } \\
\text { facilities (yes) }\end{array}$ & $\begin{array}{l}\text { with } \\
\text { noyyyyy}\end{array}$ & $\begin{array}{l}\text { Not provided } \\
\text { facilities (no) }\end{array}$ & with \\
\cline { 3 - 6 } & & Frequency & \% & Frequency & \% \\
\hline 1 & Bursary facility & 05 & 2.0 & 175 & 98.0 \\
2 & Scholarship award & 02 & 7 & 182 & 93.0 \\
3 & Subsidized tuition & 10 & 4.0 & 170 & 96.0 \\
4 & Hostel accommodation & 29 & 11.6 & 151 & 88.4 \\
5 & Computer system & 20 & 8 & 160 & 92.0 \\
6 & CD-Rom & 100 & 60.0 & 80 & 40.0 \\
7 & Instructional modules & 98 & 57.6 & 72 & 42.4 \\
8 & Internet use & 30 & 15.2 & 150 & 75.8 \\
9 & Social infrastructure for games & 52 & 20.8 & 128 & 79.2 \\
& and sport & & & & 82.0 \\
10 & Guidance and counseling & 40 & 18.0 & 140 & \\
\hline
\end{tabular}

According to Table 2, only $5(2.0 \%)$ of distance learners said that bursary facility were provided. $2(7 \%)$ claimed that scholarship award was provided. $100(60.0 \%)$ respondents agreed that they were provided with CD-Rom. These were major distance learners from the University of Nigeria Nsukka DLC centre. However, 98 (57.6\%) indicated that they were given instructional modules/course materials that facilitated active interaction. From Table 2, only CD-Rom and instructional modules appeared sufficiently provided amongst the list of facilities. Some others that were said to be provided were insufficiently provided and they appear as if not provided at all.

Table 3. Adequacy of support facilities.

\begin{tabular}{llllll}
\hline S/n & Facilities & Adequate & \multicolumn{3}{c}{ Not adequate } \\
\cline { 3 - 5 } & & Frequency & \% & Frequency & \% \\
\hline 1 & Bursary facility & 06 & 4.3 & 174 & 95.7 \\
2 & Scholarship award & 02 & 8 & 178 & 99.0 \\
3 & Subsidized tuition & 08 & 3.2 & 172 & 96.8 \\
4 & Hostel accommodation & 09 & 3.6 & 171 & 96.4 \\
5 & Computer system & 15 & 6.0 & 165 & 94.0
\end{tabular}




\begin{tabular}{llllll}
\hline 6 & CD-Rom & 140 & 76.0 & 40 & 24.0 \\
7 & Instructional modules & 125 & 74.0 & 55 & 26.0 \\
8 & Internet use & 18 & 8.8 & 162 & 91.2 \\
9 & $\begin{array}{l}\text { Social infrastructure for games } \\
\text { and sport }\end{array}$ & 20 & 12.0 & 160 & 88.0 \\
10 & $\begin{array}{l}\text { Guidance and counselling } \\
\text { services }\end{array}$ & 98 & 58.0 & 72 & 42.0 \\
\hline
\end{tabular}

From Table 3, 76.0\% of the respondents said that though they were provided CD-Rom, it was not adequately provided. $74.0 \%$ said that instructional modules were adequately provided to distance learners. Only $98(58.0 \%)$ said that they were offered adequate guidance and counseling service. Therefore, only CD-Rom, instructional modules and guidance and counseling services were indicated to be sufficiently and adequately provided amongst the list of the facilities. The self-completion item in the questionnaire was selected as the most appropriate tool to elicit responses on how distance learners cope with non-availability of some student support facilities. Of these 120 respondents, about $45 \%$ (60) said that they were surprised that the University of Nigeria Nsukka could not provide unaffordable facilities that would enhance adequate learning and student comfort. They said they had learnt to endure since the programme had a time-frame or duration. Among the remaining, one respondent (amongst the Nnamdi Azikiwe University sample) stated that the programme was hardly different from summary coaching/lesson organized for JAMB (Joint Admission and Matriculation Boards) or WAEC (West African Examinations Council) and NECO (National Examinations Commission) candidates that is often devoid of proper organization and learners' welfare. Another respondent from the Nnamdi Azikiwe University study centre stated that he hardly could distinguish between NTI (National Teachers' Institute), NCE (Nigeria Certificate in Education) with DLS (Distance Learning System) where "nothing is impossible" (this might relate to examination malpractices, exploitation through inordinate demands from learners on handouts or course materials and other inadequacies). However, some lamentably stated that since the major mode of content delivery is print, "course materials such as modules should be given to us on time, as we don't find it easy to borrow from other students who had passed through this same programme before us". Some others stated that they slept anywhere; with friends or relatives, during interactive periods, while some rented apartments or rooms elsewhere at exorbitant costs.

\section{Discussion}

Generally, the respondents indicated that though the programme is extremely good and attractive, student support facilities are not provided or are not adequately provided. Distance learners are made to suffer untold hardships which directly or indirectly affect their academic performances on the programme and their disposition towards the programme now and later in life. While it is the general belief of many that most distance education centres in Nigeria are established to generate fund for conventional programmes being run parallel to distance education by the same university (Fagbamiye, 2002), it should be noted however, that the National Policy on Education (2004) states that adequate provision for functional and remedial 
education/work-study programme that will develop the intellectual capacities of individuals to understand and appreciate their environment, thereby become useful members of the community should be provided. Therefore, universities running distance education programmes should endeavour to undergo process evaluation of their organization performance as "feedback plays a crucial role in opening and maintaining a dialogue between the centre facilitators and students so as to forestall inadequacies in programme implementation" (Hyland, 2001). Holmberg (1983) points out that empirical studies have shown that "quick handling with proper tutor comments on students' welfare in relation to their support facilities has proved essential for students' success" and Morgan (1995) says that the provision of distance students' support services encourages reflection in learning and serves as an antidote to frustration and dropping out. In the light of the foregoing, distance education institutions in Nigeria should endeavour to make the programme interesting and convenient for the learners by providing more of support facilities made available to conventional students. Distance education should be given priority on budget allocation and the issue of adequate provision of student support facilities should not be underestimated.

\section{Recommendations}

Based on the findings of the study rhe following recommendations were made;

The national policy on education should be reviewed to emphasize the inculcation, adequate provision and implementation of policy document on student support services/facilities by Nigerian institutions organizing distance education programme in their curriculum.

The Federal government should make adequate provision for the smooth running of distance education programme in the annual national budget.

Further, federal and state owned institutions running distance education programmes should provide sufficient fund to take care of student support or needs. Therefore, students' tuition should be subsidized to enable students from poor homes or self-sponsoring students meet up with the financial implications that relate to tuition and course materials. 


\section{References}

Ademokoya JA (2007). Reaching for more special needs learners in Nigeria through special distance learning. Int. J. Distant Educ.

Carr ZC, Ledwith BD (1980). Ten great tips for facilitating virtual learning teams. Proceedings of the Annual conference on distance Teaching and Learning U.S.A. 14: 19-25.

Chem L (1997). Distance delivery systems in terms of pedagogical considerations. A Revolut. Educ. Technol. 37(4): 34-37.

Daniel A (2004). Distance Education Caring for Learners in Different Sector in Dada, A. Ibadan. J. Distance Educ. 1(1).

Fagbamiye EO (2002). Open access to secondary education. The distance education option. Mimeograph.

Federal Republic of Nigeria (2004). National Policy on Education, Yaba, Lagos: NERDC Press.

Galusha JM (2006). Barriers to learning in Distance Education. The Infrastructure Network, University of Southern Mississippi. Galusha JM "Barriers to Learning in Distance Education" The Infrastruction Network. New Jersey City University, 1997. http://www.njcu.edu/.

Holmberg B (1986). Growth and structure of Distance Education. Kent, England: Croom Helm.

Hyland F (2001). Providing effective support: Investigating, feedback to Distance language learners. Open Learning. 16(3): 234-247.

Idrus RM, Lateh D (2000). Online Distance Education at the University Sains Malaysia: Preliminary Perceptions, International Council for Education Media, pp. 197-200.

Keegan D (1990). Foundations of Distance Education (2nd ed.) London. Routledge.

Kinnaman P (1995). Guide to managing a telecourse/Di-stance Learning Program. Suisun, California: Learning Resources Association.

Merill L (2003). Designing Communities for learners for asynchronous learning environments. Educ. Technol. Res. Dev. J. 46(4): 115-122. 
Moore MG, Kearsley G (1996). Distance Education: A systems View Belmont. Wadsworth Publishing company.

Mulrean J (2006). “Who Would Hire an Online Grad?” MSN Encarta. Retrieved August 2006 http://encarta.com/elearningarticlewhowouldhirearchive/.

Okebukola PAO (2007). The State of Universities in Nigeria. Ibadan: Heinemann.

Owoeye JS (2004). "An overview of the Practice of Distance Education in the University of Ibadan" in Issues in Educational Measurement and Evaluation in Nigeria in honour of Wole Falayajo. Ed. by Omaze A. Afemikhe and J. Gbenga Adewale, Educational Research and study Group, Ibadan.

Picciano AG (2006). "Online Learning: Implications for Higher Education Pedagogy and Policy". Spring 2006. Expanded Academic ASAP. http://findgalegroup.com/. J. Thought 41:1

Sampson N (2003). "Meeting the needs of Distance Learners. A mixedmode environment" in Language Learning and Technology. 7(3): 103-118.

Schamber L (1988). Delivery systems for Distance Education (ERIC Document reproduction service No. E. 304 III).

Savery JR, Duffy TM (1995). Problem-based learning. An Instructional Model and its constructivist framework. Educ. Technol. 35 (5): 31-38. 